\title{
O (anti)feminismo nas representações da virilidade na imprensa ilustrada humorística (Brasil e Argentina, 1904-1918)
}

\author{
Thaís Batista Rosa Moreira ${ }^{1}$
}

\begin{abstract}
Resumo: Este artigo tem por objetivo analisar uma série de representações ligadas ao que se entendia como virilidade no início do século $\mathrm{XX}$, especialmente quando esse conceito aparecia atrelado às relações de gênero ou ao (anti)feminismo. O período em questão é um momento-chave na história da imprensa como um todo: com os maquinários cada vez mais modernos e a circulação de notícias cada vez mais fluida, diversos periódicos são editados nos grandes centros urbanos. Uma das revistas mais populares da Belle Époque era a revista ilustrada humorística. Para a nossa reflexão, tomaremos como exemplo dois periódicos desse gênero: a revista $O$ Malho, brasileira, e a revista $P B T$, argentina. A tônica de suas publicações, que são nossas fontes primárias, era a da sátira e do humor, por meio de chistes, charges e crônicas que traziam as notícias e as novidades do mundo da política e da cultura. Nesse sentido, a questão da emancipação feminina foi um dos temas constantemente articulados e mobilizados por esses periódicos, fosse demarcando um posicionamento antifeminista ou ressignificando o termo "feminismo".
\end{abstract}

Palavras-chave: Virilidade; Feminismo; Imprensa; Representação; Humor

\section{(Anti) feminism in the representations of virility in humorous illustrated press (Brazil and Argentina, 1904-1918)}

\begin{abstract}
This article aims to analyze a series of representations linked to the understanding of virility in the early twentieth century, especially when the concept appeared associated with gender relations or (anti)feminism. The period in question is a key moment in the history of the press as a whole: with increasingly modern machinery and increasingly fluid news circulation, several periodicals were being published in large urban centers. The humorous illustrated magazine was among the most popular magazines at the Belle Époque. We base our reflection on two periodicals of this genre:

\footnotetext{
1 Mestranda no Programa de Pós-graduação em História Social da Universidade de São Paulo (USP), São Paulo, Brasil. Conta com apoio financeiro da Fundação de Amparo à Pesquisa do Estado de São Paulo (FAPESP), processo no: 2020/05001-9. É integrante do Laboratório de Estudos de História das Américas (LEHA) da USP e do Grupo de Pesquisa em Gênero e História (GRUPEG-HIST). Orcid: https://orcid.org/0000-0002-2215-7493. E-mail para contato: thais.moreira@usp.br.
} 
the magazine $O$ Malho, in Brazil, and the magazine $P B T$, in Argentina. The tone of their publications, which are our primary sources, was satire and humor, through jokes, cartoons, and chronicles that brought news from the world of politics and culture. In this sense, the issue of female emancipation was one of the themes constantly articulated and mobilized by these periodicals, whether demarcating an anti-feminist position or reinterpreting the term "feminism".

Keywords: Virility; Feminism; Press. Representation ; Humour

Artigo recebido em: 14/05/2021

Artigo aprovado para publicação em: 27/10/2021

\title{
Introdução
}

Desde fins do século XIX, o feminismo vem sendo reivindicado por mulheres (e alguns homens ${ }^{2}$ ), em geral das classes mais abastadas, como um ideal político urgente. As pautas eram diversas, contemplando desde o direito à educação formal e especializada até o acesso a determinados postos de trabalho. A reivindicação do sufrágio feminino, por sua vez, foi uma das mais eloquentes bandeiras que angariaram a atenção da imprensa ocidental, especialmente a partir das notícias sobre as suffragettes inglesas e seus manifestos por meio da desobediência civil. De todo modo, os movimentos feministas e suas contestações das desigualdades entre os gêneros marcam um longo e fervoroso debate sobre a condição das mulheres na sociedade, sobre os "papéis de gênero" do homem e da mulher e sobre seus comportamentos, dentre eles, os derivados do código viril:

\begin{abstract}
A virilidade não constitui uma simples virtude individual. Ela ordena, irriga a sociedade, cujos valores sustenta. Ela induz efeitos de dominação - dentre os quais o exercido sobre a mulher é apenas um elemento. Ela estrutura a representação do mundo (...) é por isso que virilidade não é sinônimo de masculinidade (CORBIN; COURTINE; VIGARELLO, 2013a, p. 9-10).
\end{abstract}

\footnotetext{
2 Alguns intelectuais e políticos, a despeito das contínuas críticas que receberam da imprensa, se colocaram como importantes aliados e defensores da emancipação feminina e do sufrágio. Na Europa, um dos nomes mais conhecidos foi o de J. Stuart Mill, em especial após a publicação de The Subjection of Women (1869). No contexto brasileiro e argentino, citamos como exemplos os políticos Maurício de Lacerda, Juvenal Lamartine, Alfredo Palacios, Francisco Correa e Enrique del Valle Iberlucea.
} 
Para se pensar em termos como 'código viril' e 'virilidade', é preciso defini-los e, como ressalta Alain Corbin, diferenciá-los de 'masculinidade'. A virilidade, assim como seus códigos - premissas, comportamentos e atitudes, historicamente construídos e variáveis - não são sempre definidos como oposição à feminilidade, bem como a falta de virilidade de um homem não anula, necessariamente, a sua condição como homem. Desse modo, o comportamento viril encaixa-se mais como um "tipo masculino", como se referencia Durval Muniz Albuquerque Júnior (2013, p. 208) em seu trabalho sobre o nordestino e a invenção do "falo". Outro "tipo masculino" que se fez presente no período da Belle Époque, de forma depreciada, foi o do "almofadinha"3. De todo modo, segundo Alain Corbin (2013a, p. 10), vigora no começo do século XX a ideia da virilidade como a manifestação da autoridade, competitividade, busca da superioridade, heroísmo destemido, apreço à fama e ao prestígio, controle das emoções, firmeza e ardor sexual. De acordo com o autor, essas concepções permanecem do século XIX até meados dos anos 1930, quando as fissuras deixadas pelas experiências de guerra tensionam os códigos a se redefinirem.

Como bem pontua Jean-Jacques Courtine (2013b, p. 9), as histórias da virilidade e da masculinidade não se confundem: durante muito tempo, "masculino" foi somente um termo gramatical, pois no século XIX e começo do XX, não se exortava os homens a serem "masculinos", mas "viris", homens, se dizia, "verdadeiros". Importante ressaltar, ainda, que mesmo as mulheres poderiam demonstrar virilidade, na medida em que manifestassem senso de grandeza, honra, sacrifício pela pátria: Joana D’Arc, por exemplo, é uma figura que passaria a ser exaltada como heroína nacional da França (CORBIN; COURTINE; VIGARELLO, 2013a, p. 10).

Para analisarmos algumas representações da virilidade em circulação no início do século XX, tomaremos como fontes históricas as publicações O Malho (Brasil) e

\footnotetext{
${ }^{3}$ Segundo Cláudia de Oliveira (2010), o homem "almofada", delicado e mundano, era visto como o último resquício do dandismo fin-de-siècle e tornou-se extremamente fora de lugar na construção da imagem do burguês "bem-sucedido".
} 
PBT (Argentina). A baliza cronológica de 1904 a 1918 se justifica por ser este o período em que ambos os periódicos circularam semanalmente, o que nos permitirá traçar análises comparativas. A Belle Époque foi palco de diversas manifestações políticas e sociais que não passaram despercebidas pela opinião pública, enquanto que revistas como $P B T$ e $O$ Malho foram canais de circulação das ideias do seu tempo, tendo em seu conteúdo as marcas das relações e das "normas" de gênero. Nesse artigo buscaremos evidenciar como as duas revistas, apesar de compartilharem semelhanças em seu formatos e conteúdo, apresentaram particularidades quanto à abordagem ao (anti)feminismo e às representações da virilidade. No caso argentino, mostrou-se preponderante a inquietação diante do feminismo como "ameaça à sociedade", enquanto no Brasil a maior particularidade se deu no esforço de evidenciar um suposto outro "bom feminismo", de teor sexista e patriótico, que não se engajava nas pautas de emancipação civil ou política das mulheres. O conceito de representações utilizado é o de Roger Chartier (2002, p. 17), que as caracteriza como "percepções sociais da realidade colocadas num campo de concorrências e competições, imersas em relações de poder e dominação que produzem estratégias e práticas, buscando impor autoridade, legitimidade ou justificativas de escolhas e conduta”.

Outro aporte metodológico fundamental é o do conceito de gênero como categoria útil de análise histórica. Assim como sinaliza a historiadora Joan Scott, o desafio da escrita de uma nova história deve incluir a experiência das mulheres e dar conta das persistentes desigualdades entre os homens e as mulheres - e esse movimento só é possível com a discussão do gênero como categoria analítica. É necessário frisar que uma das preocupações de Scott tem relação com a pouca importância dada ao gênero por estudiosos que abordaram temas como política e poder (SCOTT, 1995, p. 76), o que reafirma o esforço do artigo em questão, uma vez que compreende o debate sobre a emancipação civil e política das mulheres no início do século XX. Durante todo o trabalho exposto, seguiremos os apontamentos da autora, buscando encontrar as 
maneiras pelas quais o conceito de gênero legitimou e construiu as relações sociais da época, para, desse modo, compreendermos a natureza recíproca do gênero e da sociedade e as formas particulares e contextualmente específicas pelas quais a política constrói o gênero e o gênero constrói a política (SCOTT, 1995, p. 89).

Além disso, analisaremos as fontes selecionadas por meio dos aportes teóricos expostos nos volumes 2 e 3 da coleção História da Virilidade, organizada por Alain Corbin, Jean-Jacques Courtine e Georges Vigarello. O aspecto relacional dos papéis atribuídos aos gêneros será também evidenciado na medida em que a diferença sexual, na época em questão, passa a ser entendida como um dado imutável da natureza, amparada por concepções científicas e religiosas que eram reafirmadas nas representações produzidas na imprensa. Desse modo, o tipo do corpus documental privilegia, inevitavelmente, a reflexão focada no discurso. Ainda assim, a dimensão prática não está totalmente alheia, pois, como ressalta Roger Chartier (1995, p. 43), a prática e o discurso não são separados na medida em que a diferença sexual está “inscrita nas práticas e nos fatos, organizando a realidade e o cotidiano" e é "sempre construída pelo discurso que a funda e a legitima".

Assim sendo, o artigo se organiza em três partes: na primeira, intitulada "As revistas ilustradas humorísticas na Belle Époque e os (anti)feminismos”, apresentaremos o contexto histórico dos movimentos feministas da época, o papel social das revistas ilustradas e quais são as possibilidades interpretativas dos antifeminismos segundo a bibliografia existente. Em seguida, em “A necessária manifestação da energia sexual e o culto à feminilidade", analisaremos como algumas fontes estudadas produziram imagens de elogio às normas de gênero hegemônicas no início do século, como o "homem viril" e a "mulher feminina". Na última parte, de título "A ameaça dos homens sem virilidade e as "boas mulheres viris", analisaremos como os comportamentos e "papéis de gênero" foram - por meio das narrativas da imprensa - invertidos, tensionados e manipulados. 


\section{As revistas ilustradas humorísticas na Belle Époque e os (anti)feminismos}

Durante a Belle Époque, as revistas ilustradas humorísticas foram particularmente populares nos centros urbanos. Em 1905, por exemplo, revistas como $P B T$ e $O$ Malho tinham tiragens semanais em torno de 40 mil exemplares (OJEDA; MOYANO; SUJATOVICH, 2018, p.831; O Malho, 30 dez. 1905, p. 1). Esse tipo de semanário buscava familiarizar os(as) leitores(as) com a ideia de modernidade (VELLOSO, 2008, p. 214) em um notável equilíbrio entre texto e imagem, caricaturas e fotografias, notas humorísticas e colaborações literárias, de atualidade e documentais, de publicidade e entretenimento (BURKART, 2011, p. 30). A sátira política ${ }^{4}$, contudo, tinha um espaço privilegiado em suas páginas. Dito isso, ressaltamos que debruçar-se sobre essas fontes pode nos mostrar como o humor foi uma arma social e política dos impotentes, mas também um modo de incentivar laços de sociabilidade, de sublimar agressões ou ressentimentos, de administrar o cinismo e estilizar a violência (SALIBA, 2017, p. 20).

Dentre charges, viñetas humorísticas ${ }^{5}$ e textos cômicos, as publicações de $P B T$ e $O$ Malho evidenciaram muitas das normas de gênero em voga na época, como a concepção da "diferença (e desigualdade) sexual como dado da natureza". Questionar

\footnotetext{
${ }^{4}$ A sátira é uma das formas de manifestação do humor - para além do viés satírico, ele também pode se expressar por meio de comicidade, humorismo, parodia, pastiche, ironia, jogos de palavras etc. Segundo o Diccionario crítico de términos del humor y breve enciclopédia de la cultura humorística argentina, a sátira pode se manifestar pelas mais diversas linguagens artísticas e tem como característica a busca da tradução deliberada, por meio de palavras ou imagens, do que se consideram vícios sociais. Seus propósitos podem ser hostis ou moralizantes e, por vezes, de difícil distinção perante a paródia. A sátira pode fazer uso da burla (escárnio), da zombaria, da ironia e da indignação. Ver em: FLORES, 2014, p.123.

${ }_{5}^{5}$ De acordo com o Diccionario crítico de términos del humor y breve enciclopédia de la cultura humorística argentina, a viñeta humorística, também chamada de "chiste gráfico", não é o mesmo que historietas (apesar de existir a nomenclatura genérica "quadrinhos"). No chiste gráfico/viñeta humoristica, a história narrada tem começo e fim em uma única publicação, já nas historietas, há continuidade da narrativa entre uma e outra aparição nas publicações. Ver em: FLORES, 2014, p.33.
} 
essa hierarquia de gênero, por outro lado, era tido como absurdo, de modo que a ridicularização e a vulgarização do feminismo se fizeram muito presentes nas páginas desses periódicos como estratégia antifeminista importante no sentido de banalizar a seriedade da emancipação feminina, por vezes distorcendo o seu significado (BESSE, 1999, p. 214). O termo 'feminismo' e os ideais de emancipação feminina eram frequentemente assunto da imprensa e refletiam, de certo modo, o cenário de mobilizações da época. No âmbito internacional, as campanhas sufragistas tiveram grande destaque nos noticiários, em especial os atos promovidos pelo grupo Women's Social and Political Union (WSPU), fundado em 1903, que ganhou fama como suffragettes - termo inicialmente pejorativo, cunhado pela imprensa inglesa.

No que diz respeito ao contexto latino-americano, havia, já no início do século $\mathrm{XX}$, diversos grupos organizados que atuavam em associações ou por meio da imprensa. Mulheres militantes anarquistas, que nem sempre adotaram ou aceitaram a denominação "feminista", tiveram papel importante na produção de uma visão crítica sobre determinadas normas de gênero em voga - no caso brasileiro, destaca-se a atuação de Maria Lacerda de Moura, que denunciava o culto da virgindade, a ideia de "honra masculina" e a hipocrisia reinante na organização da família com seu complemento, a prostituição (BESSE, 1999, p. 47; SOIHET, 2013, p. 121), Já na Argentina, a voz das anarquistas ecoou em periódicos semiclandestinos desde fins do século XIX, tendo como exemplo marcante o La Voz de la Mujer (PRADO, 2015, p. 73). Por outro lado, grupos que se movimentavam em torno de demandas sufragistas e por direitos civis também se fizeram presentes. No Brasil, o Partido Republicano Feminino (PRF), fundando em 1910, pela professora Leolinda Figueiredo Daltro, buscou disseminar ideias sobre a emancipação feminina. Na Argentina, várias organizações se formaram: o Centro de Universitarias Argentinas (1904), o Centro Feminista (1905) e o Comitê Pro-Sufrágio (1907) são alguns exemplos. Houve ainda as duas primeiras tentativas de 
legalização do voto feminino, com os projetos de Alfredo Palacios (1911), na Argentina, e Maurício de Lacerda (1917), no Brasil.

Essas várias dimensões do feminismo - que envolviam tanto a luta por direitos quanto o questionamento de certos constrangimentos e normas de gênero - encontraram fértil oposição na imprensa. Os posicionamentos antifeministas negavam, de diferentes formas, a legitimidade de ações voltadas à conquista de direitos e dignidade às mulheres. A questão da igualdade entre homens e mulheres transcende oposições tradicionais do "xadrez político" (ROCHEFORT, 1999, p. 138), de modo que interlocutores tanto conservadores como progressistas/reformistas manifestaram suas convicções antifeministas, enfatizando a "natureza complementar dos sexos" (BESSE, 1999, p. 68). Alguns trabalhos já buscaram compreender os discursos antifeministas e/ou misóginos, sendo a diversidade de interpretações apresentadas um indicativo de que o campo de estudo permanece relevante e aberto ao debate. Para Peter Gay (1988), o "medo da mulher" e o "medo diante das mudanças" se fundiam nas frequentes críticas à emancipação feminina. Branca Moreira Alves (2019, p. 49) expõe seu sentimento de indignação e incompreensão sobre que razões explicariam a ferrenha e constante resistência aos direitos das mulheres, pontuando que esta é ainda uma pergunta sem resposta, mas que pode encontrar uma explicação no "temor primordial dos homens em relação ao sexo feminino”. Florence Rochefort (1999), pensando no contexto feminista francês da Belle Époque, buscou compreender a lógica do discurso antifeminista como uma comunicação eficaz e persuasiva, atrelando-a ao conceito de "retórica reacionária" de Albert O. Hirschman. Por fim, destaca-se a análise de Rachel Soihet (2013), que trabalhou com as revistas ilustradas do começo do século - Careta e Fon-fon! - e com o famoso periódico Pasquim, publicado entre o final da década de 1960 e 1980 . A autora mobilizou em sua pesquisa os conceitos de "zombaria" de Quentin Skinner e de "violência simbólica" de Roger Chartier. 
No artigo em questão, buscaremos analisar o antifeminismo pelo fio condutor das representações da virilidade. Sem desconsiderarmos as interpretações e explicações já mencionadas, propomos, a partir da recorrência nas fontes, eleger como foco analítico a prática da imprensa de mobilizar conjuntamente os códigos viris e os julgamentos ao feminismo. Dessa forma, serão destacadas as semelhanças e diferenças entre a revista argentina e a brasileira.

\section{A "necessária manifestação da energia sexual" e o culto à feminilidade}

Ao analisar um conjunto de correspondências trocadas entre homens em meados do século XIX, Alain Corbin (2013a, p. 153) deparou-se com uma série de representações e "normas" da virilidade, que, como ele mesmo diz, se exprimiam sem rodeios de palavras. Segundo o autor, o antissentimentalismo e o esforço em medir o "grau de intensidade" dos exercícios da virilidade era uma conversa corriqueira entre esses sujeitos. Comportamentos audazes e lascivos eram parte do código viril em voga, de modo que os assédios sexuais eram justificados como "efeitos da necessidade dos homens em concretizar atos sexuais" (CORBIN, 2013a, p. 154). É importante ressaltar que esses comportamentos viris dos homens foram concomitantes com um processo de "saída às ruas" das mulheres mais abastadas, incentivadas por mudanças na indumentária e nas próprias paisagens urbanas. Para essas mulheres, o lazer significou a conquista de novos territórios, em que elas vão às ruas para despender seu tempo livre nas lojas, nos parques, nos teatros, nos campos de esportes e nos clubes recreativos (MELO, 2007 apud GONÇALES, 2019, p. 124).

Na charge a seguir, publicada na revista $O$ Malho, ambos os comportamentos são retratados: no Rio de Janeiro de 1911, em um cenário que remete à beira do mar, uma mulher burguesa, vestida com acessórios e roupas de passeio - traje comum para caminhar na praia (GONÇALVES, 2019, p. 125) - é observada por um homem que demonstra, por seu olhar malicioso, suas intenções sexuais. As personagens estão 
orientadas na mesma direção, sem que a mulher visualize ou se comunique com o homem, o que pode sugerir que ela é seguida pelo sujeito.

\section{Imagem 1 - Feminismo carioca}

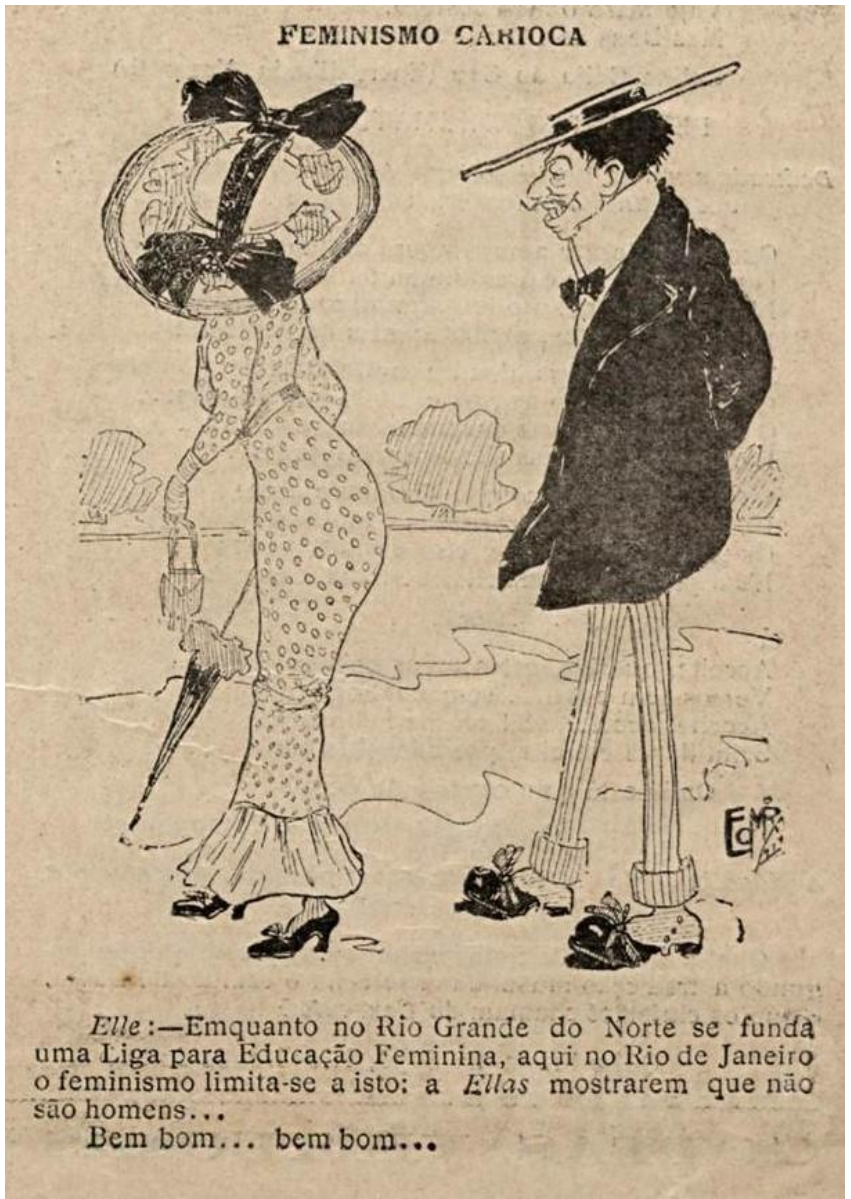

"Feminismo carioca", revista $O$ Malho (Brasil), 15 de julho de 1911. Reprodução do Acervo Digital da Fundação Biblioteca Nacional (BNDigital)

Um erotismo ousado permeava o imaginário masculino moderno na construção da nova mulher carioca nas revistas ilustradas, de forma a explorar da imagem da mulher em uma verdadeira perseguição visual (OLIVEIRA, 2010, p. 210-211). Nessa charge, o autor-ilustrador atribuiu à mulher carioca a representação do "feminismo 
local”, com a finalidade de compará-la às feministas do Rio Grande do Norte, que, segundo ele, fundaram uma "Liga para Educação Feminina"6. É importante ressaltar, primeiramente, que apesar da narrativa explorar uma suposta disparidade entre as concepções de feminismo nas duas regiões brasileiras - o que pode ser interpretado como uma retórica da "desorganização feminista", um argumento utilizado com frequência pelos articulistas antifeministas -, os acontecimentos contemporâneos indicavam o oposto. No fim do ano anterior, a professora Leolinda Figueiredo Daltro havia fundado o Partido Republicano Feminino, que, apesar de sediado no Rio de Janeiro, deixava clara em seu estatuto, publicado no Diário Oficial de 17 de dezembro de 1910, a pretensão de amplitude nacional por meio de subsedes regionais.

O modo como Elle - a personagem masculina em cena na charge - se refere aos feminismos em sua primeira fala parece ambígua, pois não fica claro qual feminismo é o objeto de sua crítica. No entanto, o desfecho narrativo sugere um forte teor irônico no dito "limitado" feminismo carioca. Para o sujeito da charge, a atuação feminista do Rio de Janeiro é descrita como a exacerbação da feminilidade e da exibição dos corpos femininos nas ruas - em função e em disposição para os homens, sobretudo. É marcado por uma visão sexista que objetifica as mulheres, entendendo que a maior circulação de parte delas tornavam-nas vulneráveis aos assédios, que seriam "justificados" por atender às "necessidades masculinas" de manifestar energia sexual, visível na expressão do personagem em cena. Mesmo em se tratando de uma charge - uma ficção - essa representação do código viril é tão sintomática quanto o "assumido por seres de carne", que é o caso das análises de Alain Corbin. Aqui, a representação da virilidade no personagem poderia, aos olhos da época, ser entendida como um "comportamento normal" dos homens transeuntes. Além de tudo, ao associar a situação de assédio à

\footnotetext{
${ }^{6}$ Segundo o pesquisador Cosme Ferreira Marques Neto, em 1911 foi fundada a Liga de Ensino do Rio Grande do Norte, projeto de modernidade pedagógica engendrado por Henrique Castriciano de Souza (1874-1947). A educação feminina e a pedagogia ménagère era um dos motes da Liga, que se expande em 1914 com a criação da Escola Doméstica de Natal. Ver em: MARQUES NETO, 2016.
} 
palavra 'feminismo', a charge deturpa os possíveis entendimentos sobre ideias feministas ao mesmo tempo em que constrói a imagem do movimento local como "conivente" às violências cotidianas que as mulheres enfrentavam no espaço público ${ }^{7}$ ou seja, a charge carregava um potencial de constranger as suas leitoras ao não se identificar com a palavra 'feminismo', fenômeno típico da violência simbólica ${ }^{8}$.

Outra interpretação possível é a de que existe um sutil desdém diante da iniciativa potiguar. Esse tipo de atitude desdenhosa, que Corbin (2013a, p. 161) associa ao antissentimentalismo, era frequentemente evocado pela ironia, como é o caso na publicação de $O$ Malho. A mobilização no Rio Grande do Norte para estimular a educação das mulheres é vista como o desejo de "torná-las homens", o que o personagem explicita em "aqui no Rio de Janeiro o feminismo limita-se a isto: a Ellas mostrarem que não são homens...Bem bom...bem bom...". A acusação de que o feminismo mais engajado - organizado em associações e atos políticos - visava "masculinizar" as mulheres é um discurso muito presente na época e foi tema de diversas publicações das revistas ilustradas. Por outro lado, denuncias às "mulheres masculinas" não era algo novo. Existem outros exemplos já estudados em periódicos do século XIX, como o New York Herald de 1852, citado por Peter Gay (1988, p. 143), em que o articulista equiparava as feministas de Seneca Falls a "galinhas que cantam no terreiro" e os homens que assistiam às convenções feministas como "maridos dominados por suas mulheres".

\footnotetext{
${ }^{7}$ Como explicita Mônica Schpun, na época "andar na rua sem a companhia de um homem ou de uma mulher mais velha é uma situação de aventura, em que as moças se expõem a perigos". Ver em: SCHPUN, 1999, p. 39.

${ }^{8}$ Soihet (2013) chama a atenção para esse fenômeno em seus trabalhos, citando o conceito mobilizado pelo historiador Roger Chartier. Segundo o autor, a violência simbólica supõe a adesão pelos dominados das categorias que embasam a sua dominação (CHARTIER, 1995).
} 


\section{Imagem 2 - La defensa femenina}

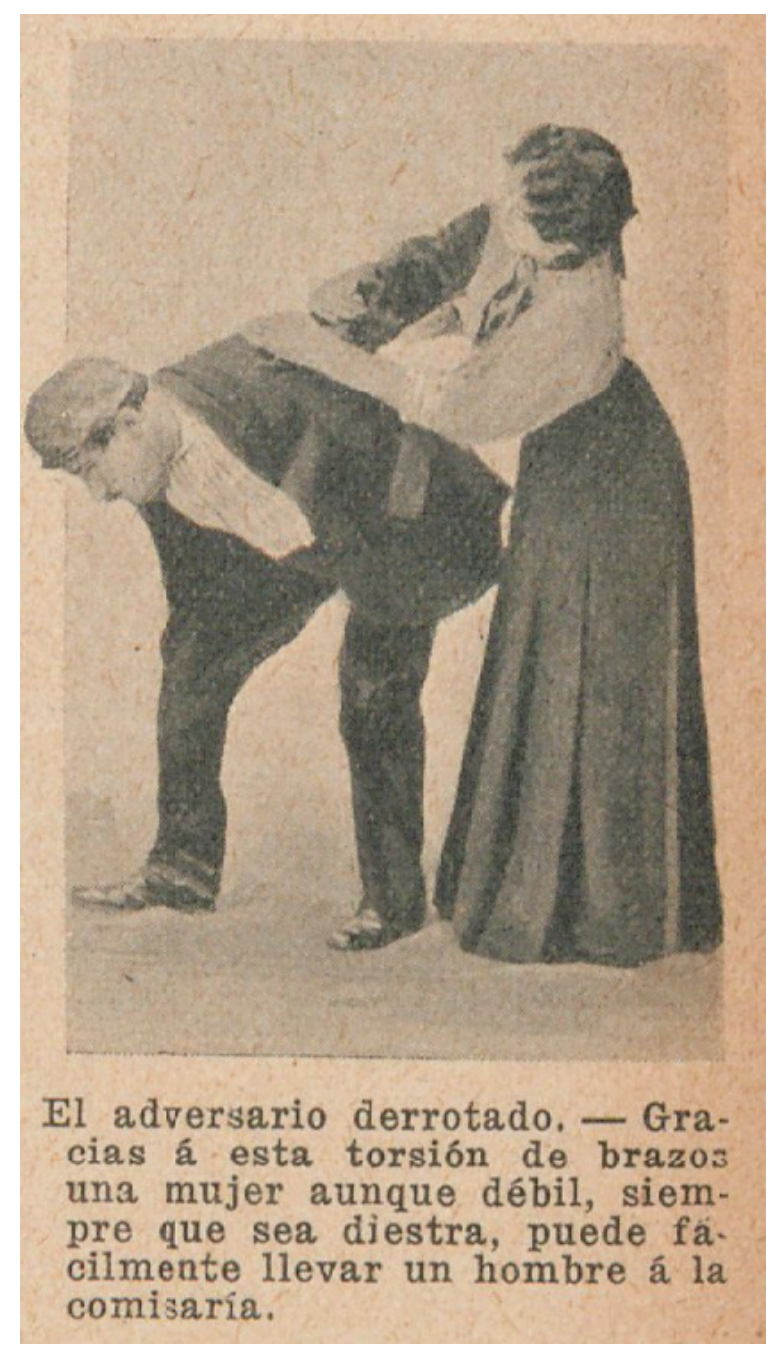

La defensa femenina, revista PBT (Argentina), 20 de março de 1909. Reprodução do acervo digital do Ibero-Amerikanisches Institut - IAI SPK (Berlim).

A revista $P B T$ pareceu adotar uma posição mais crítica quanto aos assédios que as mulheres sofriam no espaço público. Na reportagem "La defensa feminina", de teor não-humorístico, destaca-se uma detalhada explicação ilustrada das táticas de defesa pessoal que as mulheres "poderiam adotar" caso fossem vítimas de "impertinentes", tentativas de agressão ou de assalto. A reportagem dava exemplos de golpes que poderiam imobilizar os homens assediadores, como a torsão de braço ilustrada na imagem, de "fácil execução" por mulheres destras, "mesmo que fracas". Por sua vez, as 
críticas ao comportamento viril abusivo não são atreladas a qualquer "ideal feminista", sendo mais provável a sua relação com o alarmismo local quanto à criminalidade urbana, tema evocado com frequência na imprensa portenha, muitas vezes justificando a desordem e a ilegalidade como "efeitos da população migrante" na Argentina (BLACKWELDER; JOHNSON, 1982, p. 364). Outras fontes da revista PBT, como o reclame "Él respecto a la mujer" (21/03/1908) e a crônica ilustrada "Lógica femenina" (25/10/1913), mobilizam narrativas semelhantes: mulheres que caminham nas ruas de Buenos Aires são interpeladas por homens estranhos e a situação é interrompida por agentes de ordem pública que multam os sujeitos por "faltar com respeito ao bello sexo".

O elogio e o resguardo da feminilidade das mulheres foi um dos discursos muito presentes na imprensa da época. A imagem mais conhecida é a da mulher "rainha do lar”, a da mãe dedicada aos filhos e ao marido. Porém, outras figuras foram representadas, e uma delas é a da mulher branca e abastada que "cultiva o aperfeiçoamento corporal”, que se esforça continuamente para manter-se bela, executando movimentos harmoniosos e equilibrados. Isso porque o exercício físico passou a ser enaltecido para a saúde do corpo e da alma, adaptando os corpos e as mentes às demandas acelerada das novas tecnologias (SEVCENKO, 1998 apud GONÇALVES, 2019, p. 122). É o caso presente em El box femenino: 


\section{Imagem 3 - El box feminino}

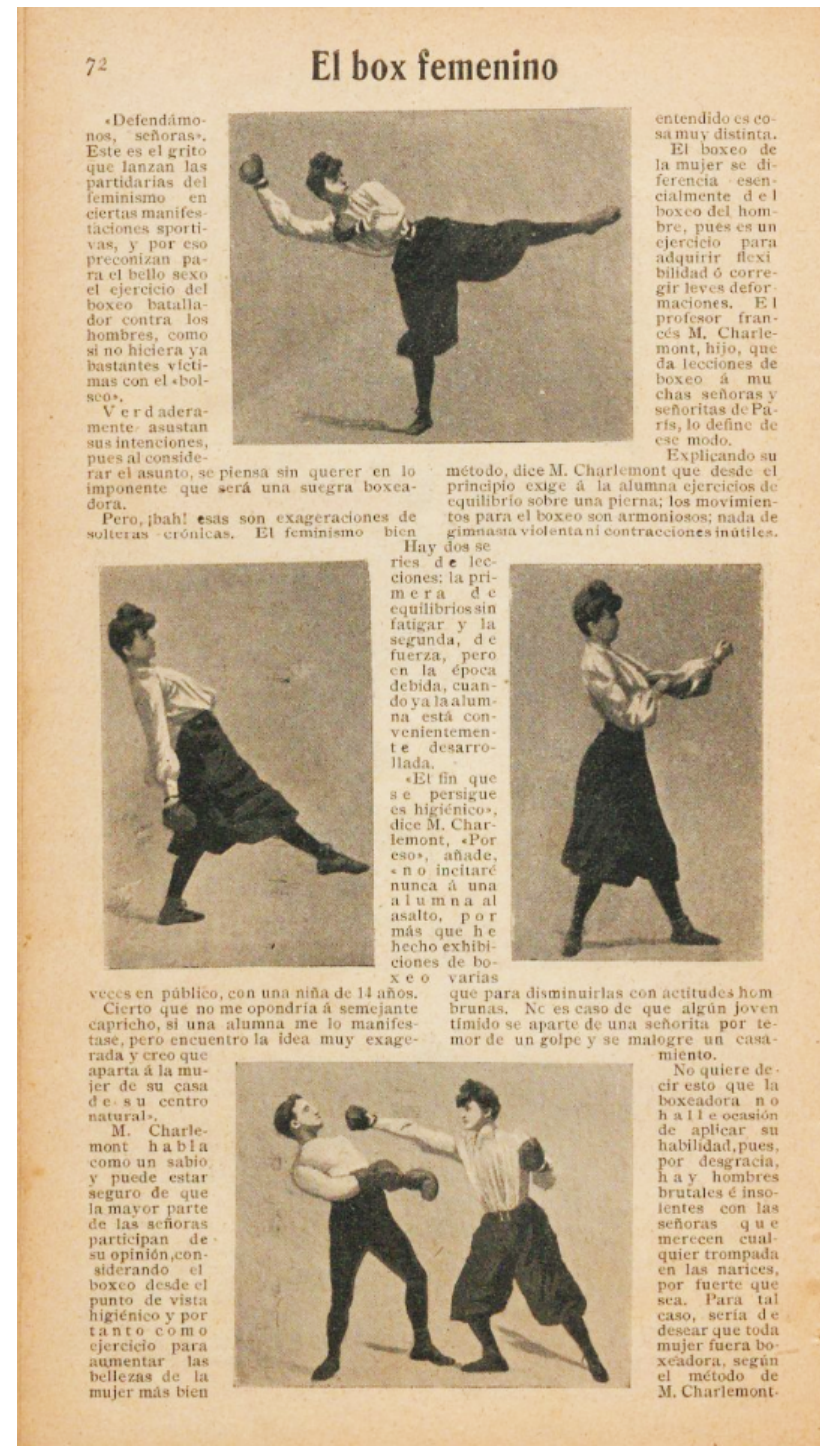

El box feminino, revista PBT (Argentina), 23 de outubro de 1904. Reprodução do acervo digital do Ibero-Amerikanisches Institut - IAI SPK (Berlim).

O texto começa da seguinte forma: “'Defendámonos, señoras'. Este es el grito que lanzan las partidarias del feminismo en ciertas manifestaciones sportivas, y por eso preconizan para el bello sexo el ejercicio del boxeo batallador contra los hombres, como si no hiciera ya bastante víctimas con el 'bolseo"'. O autor, já em suas primeiras palavras, distancia-se de um possível elogio ao feminismo, associando a sua atuação 
como uma "batalha contra os homens". Em seguida, mobiliza o estereótipo da futilidade feminina, frequente na época em falas satíricas que atribuíam às mulheres o hábito de ser "gastadeiras" que "já atacavam os homens com o bolso". As mulheres fúteis, segundo esses articulistas, eram sempre mesquinhas e incapazes de manter a estabilidade financeira - o que soa irônico, uma vez que, de acordo com os códigos civis da Argentina e do Brasil, qualquer trâmite econômico feito ou desejado por uma mulher casada deveria ser autorizado por seu marido.

Nas frases seguintes, o narrador pontua: "Pero, ;bah! esas son exageraciones de solteras cronicas. El feminismo bien entendido es cosa muy distincta”. Nota-se nesse trecho um outro insulto muito comum nos dizeres antifeministas, que é o de cunhar às partidárias o status de "solteira crônica" ou "solteirona", uma alusão a que as reivindicações feministas seriam fruto de uma suposta frustração sexual. Além disso, lança mão do termo "feminismo bien entendido", que na realidade correspondia aos ideais de feminilidade e de culto da beleza que deveriam ser exaltados em contraposição ao "feminismo partidário". O "feminismo bem entendido" era, em outras palavras, o feminismo aceitável para os padrões sexistas da época - assim como a própria imagem da Gibson Girl que ilustra o texto. Branca, magra, de penteado preso e vestimentas marcantes, a Gibson Girl foi uma imagem cultural criada nos Estados Unidos como um símbolo idealizado das mulheres modernas do fim do século XIX. Valorizar um padrão beleza e buscar aprimoramentos físicos compunham essa nova feminilidade, que, por sua vez, jamais ultrapassava certos limites: a Gibson Girl poderia até praticar tênis, mas nunca participaria da política (PATTERSON, 2008, p. 23).

Em seguida, o articulista esclarece que o boxe feminino ao qual ele se refere não é nada mais que alguns exercícios de flexibilidade voltados à correção de leves deformações: "los movimientos para el boxeo son armoniosos, nada de gymnasta violenta ni contraciones inutiles". Esse é um ponto interessante do texto, pois, de fato, as práticas físicas que serviam ao culto da beleza eram parte de um código de movimentos tidos como belos, harmoniosos e graciosos, que permitiam a expressão da “natureza feminina" (SCHPUN, 1999, p. 45). Desse modo, a prática elogiada é a da 
cultura física feminina que passa pelo critério de beleza e seu aperfeiçoamento como forma de assegurar a harmonia social, o que condiz com o discurso eugenista da época (SCHPUN, 1999, p.38; BESSE, 1999, p. 102). Entretanto, vigorava também a sexualização das modalidades esportivas, baseadas em determinações ditas "naturais" de que os corpos femininos e masculinos eram "essencialmente diferentes", de forma que a prática desportiva comum entre os sexos se deu tardiamente, salvo raras exceções. $\mathrm{O}$ treino do boxe dificilmente era aceito como adequado às mulheres, assim como o futebol, a luta romana, o levantamento de peso, as corridas de longa distância e o salto em altura, vistos como esportes "violentos" (BESSE, 1999, p. 139). Assim sendo, compreendemos a insistência do autor em distanciar o esporte da violência, descrevendo os movimentos como "harmoniosas lições de equilíbrio". O boxe "tradicional" era reservado aos homens, e mulheres que "cogitassem a sua prática" - como as citadas "partidárias do feminismo, solteiras crônicas" - não teriam qualquer respeito ou consideração.

As fontes destacadas até o momento nos sinalizam que parte das representações da virilidade eram indissociáveis ao culto da feminilidade - que, por sua vez, era colocado como o oposto ao "feminismo militante", que compreendia as atuações organizadas por grupos ou associações pró-feministas. Assim, esses articulistas delimitavam qual feminilidade e quais comportamentos julgavam respeitáveis e legítimos para as mulheres, demarcando também os limites, sempre ultrapassados pelas ativistas. Propagar que as feministas eram mulheres "masculizadas" que almejavam a um status viril inaceitável foi um esforço contínuo de autores antifeministas - e manejar a dualidade entre as "feministas degeneradas" e as "mulheres ideias" foi um recurso bastante eficaz para isso. Ademais, o discurso médico do período entendia que as mulheres que violavam as normas de gênero o faziam por "atribuição errônea" de sua identidade ou por questões patológicas - seus comportamentos dotados de "perversões do instinto sexual" compreendiam desde a homossexualidade feminina até a exigência de igualdade legal, o direito ao voto e a possibilidade de trabalhar (BEN, 2000, p. 262). 
Além de reprodutores da violência simbólica, esses textos e imagens contribuíram para uma retórica de ressignificação do termo "feminismo". São os homens da imprensa que dividem e decidem arbitrariamente, embasados pelas concepções sexistas das mais diversas ordens, quais eram o feminismo "bom" ou "ruim", "bem entendido" ou "exagerado". Destacar esse processo de apropriação e manipulação do termo é essencial para situarmos os discursos sobre os feminismos na imprensa, especialmente porque o ato privilegiado de nomear muitas vezes abre o acesso a modos de comunicação e os habilita a projetar uma interpretação, uma definição, uma descrição de seu trabalho e de seus atos que pode não ser exata (HOOKS, 2013, p. 86). Esses diversos usos do termo, no caso da Argentina, também foram uma marca das disputas de sentidos entre grupos de mulheres do início do século XX. Em 1906 era possível encontrar grupos católicos referindo-se a certo "feminismo cristão" como "verdadeiro feminismo", que deveriam se diferenciar dos "feminismos socialistas" e "revolucionários" (NARI, 2004, p. 228 apud PRADO, 2015, p. 81).

\section{A ameaça dos homens sem virilidade e as "boas mulheres viris"}

A relação de contraste entre homens e mulheres representados nessas publicações é baseada no modelo do dimorfismo sexual radical, vigente desde o século anterior. Para essa concepção, a divergência biológica entre os sexos era dada pela incomensurabilidade anatômica e fisiológica entre ambos (LAQUEUR, 2001, p. 17). Essa visão binária, por consequência, reafirmava uma série de oposições e diferenças tidas como fundamentais entre os sexos, alcançando até a dimensão comportamental. Dessa forma, a mulher é colocada como naturalmente emocional e afetiva, tendo em vista a maternidade como função primordial de sua vida. O homem, por sua vez, seria a manifestação da razão, apto à vida pública, ao comando. Não só os dogmas religiosos constroem esse discurso da dominação masculina: no final do século XVIII, os cientistas naturalistas impuseram explicitamente o homem como "membro da espécie que domina a criação" (CORBIN, 2013a, p. 9). A virilidade, assim, é reivindicada na medida em que o sujeito cumpre o papel de dominador, de autoridade. 
As ideias feministas, tidas como "ameaças da modernidade", foram interpretadas por muitos como uma afronta à "ordem natural" estabelecida e explicada pelo modelo do dimorfismo sexual. Assim sendo, o reforço do binarismo foi uma das "frentes de resistência" dos antifeministas, e um dos modos de ressaltá-lo foi a criação de narrativas humorísticas que mobilizaram situações de inversão dos “papéis de gênero". A inversão em si, como recurso linguístico, é mencionada na teoria da comicidade de Henri Bergson, e o seu teor humorístico se assegura quando, ao se deparar com a imagem invertida, o receptor tem em mente a imagem original. Assim, o riso provém do 'mundo às avessas', especialmente quando a situação se volta contra quem a criou (BERGSON, 1983, p. 46). Deslegitimar as demandas por direitos às mulheres passava pela contínua afirmação de que o feminismo incitava a ocupação dos espaços masculinos, e, além disso, pela crítica aos "sujeitos pouco viris", que contribuíam, por sua passividade, com a ascensão dos ideais feministas. Segundo os ideais burgueses em voga, os corpos masculinos deveriam se diferenciar por completo de tudo que pudesse ser percebido como pertencente ao universo feminino (GARB, 1998, p. 38 apud OLIVEIRA, 2010, p. 186), o que indica o grau de alarmismo que esses posicionamentos buscavam instaurar. A história em quadrinhos a seguir, publicada na revista $P B T$, trabalha com esse discurso: 


\section{Imagem 4 - La cuestión feminista}

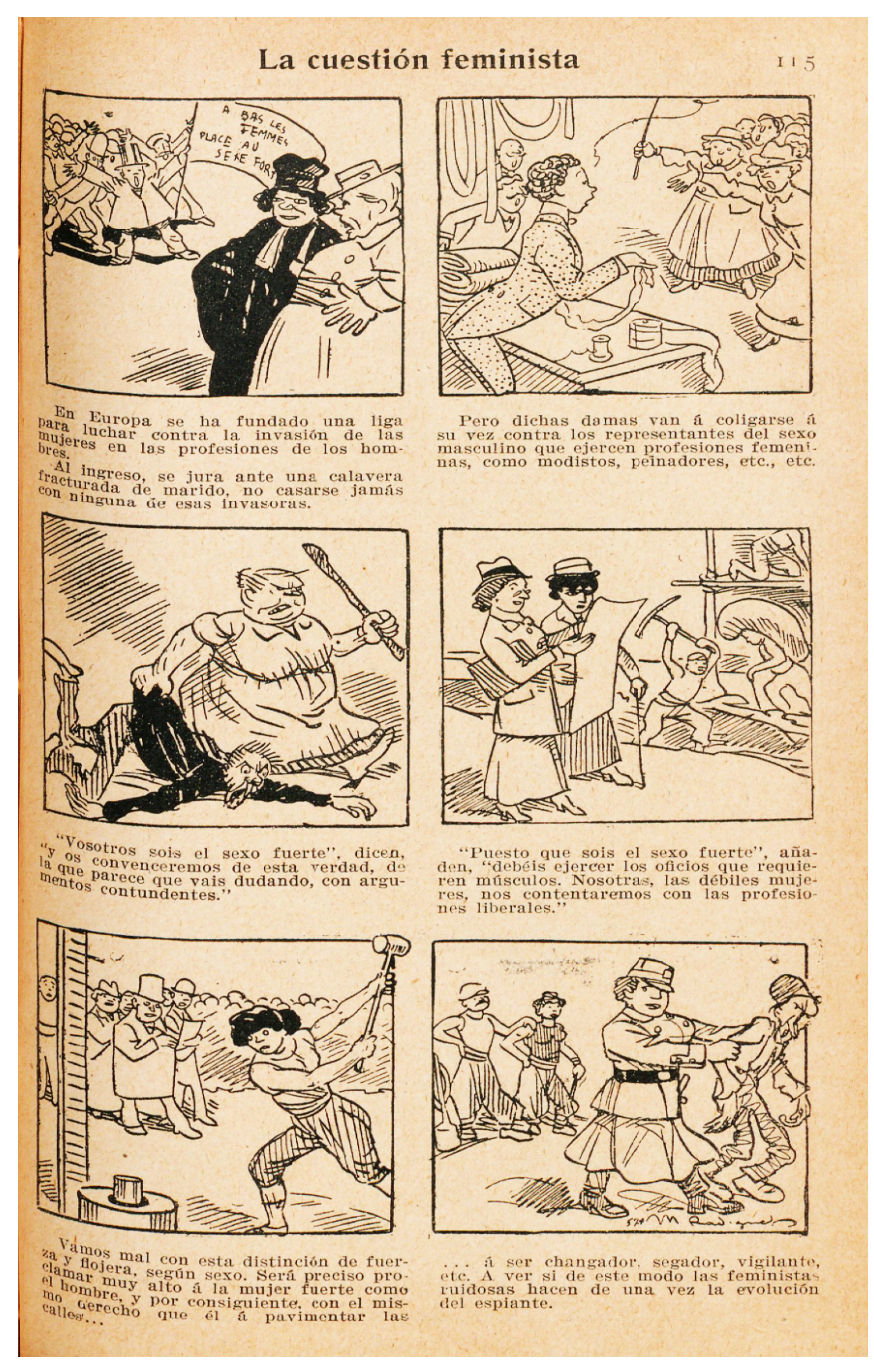

La cuestión feminista, revista PBT (Argentina), 14 de agosto de 1909. Reprodução do acervo digital do Ibero-Amerikanisches Institut - IAI SPK (Berlim).

Em La cuestión feminista, o narrador informa que na Europa foi fundada uma Liga para "lutar contra a invasão das mulheres nas profissões dos homens" (tradução livre). É a partir daí que se evoca a primeira representação da virilidade na viñeta humorística - ou, melhor dizendo, a representação da ausência da virilidade. No segundo quadrinho, aparece um modista diante das militantes feministas, que é descrito como um dos "representantes do sexo masculino que exercem profissões femininas". O personagem ilustrado corresponde ao arquétipo "almofadinha", do homem delicado e 
passivo, interessado somente em modas e frivolidades. É um dos estereótipos culturais que mais aparecem no fim do século XIX e começo do XX, sendo constantemente utilizado em narrativas conservadoras sobre as feministas, pois era, tal qual elas, associado à decadência das sociedades (OLIVEIRA, 2010, p. 187).

Outro sujeito pouco viril aparece logo em seguida, no terceiro quadrinho: é o marido "subjugado" pela esposa, ao ponto de sofrer violência física e não ter nenhuma autoridade no lar. Essa figura é interessante por mostrar a sutileza da representação cômica quando tem intenções pejorativas. Os chistes sobre "temáticas conjugais" frequentemente traziam a ideia do "abuso feminino" e da "futilidade feminina" já mencionada, apresentando as mulheres como consumistas desenfreadas que não se importavam com as finanças familiares. Nessas narrativas, os homens se queixam das supostas atitudes das mulheres, mas jamais se colocavam como inferiores, como dominados - como é o caso do quadrinho em questão. Para os olhares antifeministas da época, ambos os personagens homens demonstram carência de virilidade, o que os configura também como "cúmplices" do feminismo, pois "permitem" que a "inversão dos papéis" aconteça.

Em seguida, o narrador apresenta o que seria a fala das feministas que visam profissionalizar-se em determinadas áreas: "Pues que sois el sexo fuerte (...) debéis ejercer los oficios que requieren músculos. Nosotras, las débiles mujeres, nos contentaremos con las profisiones liberales". É importante ressaltar que, para além das demandas pela educação e pelo sufrágio, a questão da profissionalização também era reivindicada por boa parte das mulheres feministas desde fins do século XIX. Em 1887, no Brasil, Francisca Senhorinha da Motta Diniz publicou em seu jornal $O$ Sexo Feminino o seguinte texto:

A mulher instruída, convenientemente, pode à vontade e com toda dignidade e propriedade de seu sexo ocupar o emprego de médico, de químico, naturalista, físico, farmacêutico, pintor, telegrafista, botânico, agente de correios, negociante de rendas, sedas, fitas e muitos outros, próprios do lar doméstico. Para professoras do sexo forte, nem padece dúvida, visto que, em algumas províncias do Império, como a de Minas Gerais, por exemplo, muitas cadeiras do sexo masculino são regidas por senhoras (BERNARDES, 1989, p. 140). 
A questão da profissionalização também era debatida entre as argentinas. $\mathrm{O}$ Consejo Nacional de Mujeres, de caráter conservador, organizou em maio de 1910 uma reunião cujos temas de discussão foram a educação técnica para mulheres e a regulamentação do trabalho industrial feminino e infantil (LAVRIN, 2005, p. 326). Entre os grupos socialistas de mulheres engajadas - em que atuavam Elvira López, Alicia Moreau, Carolina Muzilli e outras - as preocupações eram ainda mais especializadas, com debates sobre a insalubridade nos ambientes de trabalho e as relações desiguais de trabalho para as mulheres (PRADO, 2015, p. 80). Não obstante, muitas dessas militantes reproduziam discursos "moderados" no que tange o acesso das mulheres a determinadas profissões, partindo da concepção de que havia esferas estritamente separadas entre o feminino e o masculino. Podemos observar isto nas palavras de Elvira López, na introdução de sua tese de doutorado de 1901: "Es preciso que la mujer pueda practicar todas aquellas profesiones que no sean contrarias a su dignidade y a su sexo. La mujer debe ser siempre mujer; no saliéndose de su esfera es como puede estar segura de conseguir el triunfo de su causa" (LÓPEZ, 2009, p. 36).

A viñeta humorística de $P B T$, por sua vez, posiciona a ambição feminista como alheia a qualquer moderação: as mulheres representadas estão determinadas a ocupar todo o espaço tido como masculino. Além disso, a demanda feminista é caracterizada como um "oportunismo", pois as personagens mobilizam a sua "fraqueza" para dispensar certos labores. Esse tipo de narrativa aparece em outras fontes históricas similares, de modo que o articulista, do ponto de vista masculino, produz uma sensação de injustiça ao leitor: "será preciso proclamar muy alto á la mujer fuerte como el hombre, y por consiguinte, con el mismo derecho que él à pavimentar las calles" (quinto quadrinho). Em última instância, o argumento antifeminista implícito é de que a emancipação feminina é injusta, pois pretende conceder às mulheres alguns "privilégios", e não direitos. 


\section{Imagem 5 - El feminismo práctico}

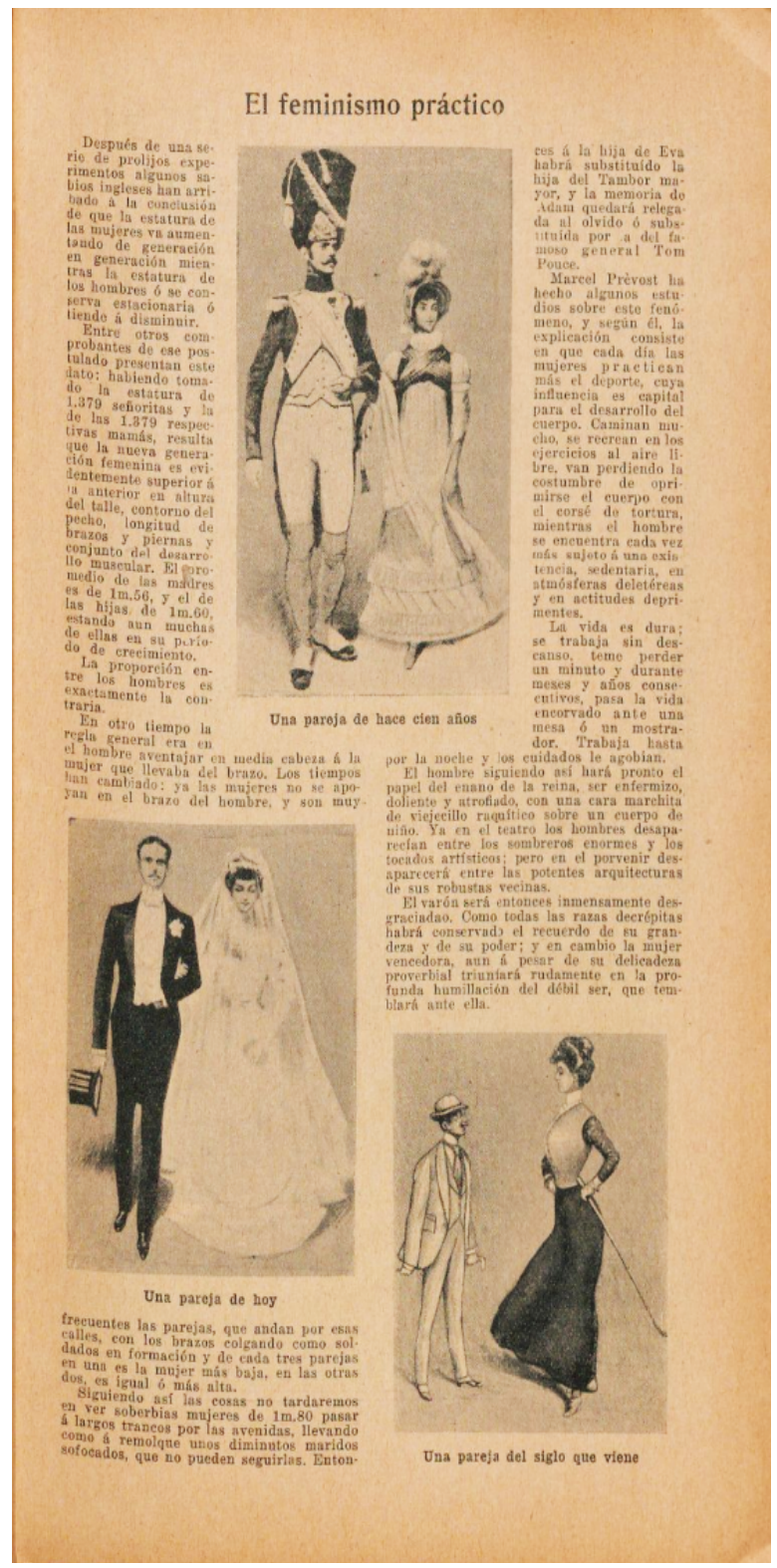

El feminismo práctico, revista $P B T$ (Argentina), 20 de agosto de 1910. Reprodução do acervo digital do Ibero-Amerikanisches Institut - IAI SPK (Berlim). 
El feminismo práctico é um texto ilustrado 9 que trata das estaturas de homens e mulheres e suas (supostas) mudanças na modernidade. Destacamos, logo de início, que o aspecto gráfico dessa publicação contém um detalhe importante: enquanto as duas primeiras imagens (zona superior e lado esquerdo) são parecidas com reproduções fotográficas, a última imagem, que sintetiza a crítica do texto, se assemelha a um típico desenho das historietas. É irônico que, na tentativa de denunciar "os males promovidos por um feminismo na prática”, o autor tenha recorrido a uma representação mais imaginária (o desenho) que as fotografias, maior expoente da pretensão de correspondência com o real dentre as formas iconográficas. Acentuar imagens fictícias e alarmistas era prática comum entre os antifeministas, mas no caso dos argentinos, ela se mostrou frequente, permeada por uma inquietação e um temor diante das reivindicações feministas. De certa forma, o contexto político do país dava margens para esses discursos apreensivos: em 1910, ano do Centenário Argentino, já atuavam no país diversas organizações feministas, inclusive de espectros políticos e atuações variadas, indo desde o mais conservador Consejo Nacional de Mujeres até às mais progressistas como o Centro de Universitarias Argentinas, o Centro Socialista Feminino e a Liga Feminista Nacional de La Plata (LAVRIN, 2005, p. 326-327).

O texto publicado em $P B T$ começa com a menção a um suposto estudo feito na Inglaterra que "constatou alterações corporais humanas no últimos anos", de modo que as mulheres estariam cada vez mais altas, e os homens, por sua vez, mais baixos. Sendo esse um período em que ideias variadas sobre a eugenia circulavam na sociedade, o texto alia a "percepção científica" da inversão das estaturas com um sentimento de desprezo ao que se anunciava como moderno: "Los tiempos han cambiado: ya las mujeres no se apoyan en el brazo del hombre (...) y de cada tres parejas en una es la mujer más baja, en las otras dos, es igual ó más alta." Assim, o articulista traz à tona a disparatada ameaça do "mundo às avessas", ressaltando a carência de virilidade entre os homens: "no tardaremos en ver soberbias mujeres de 1 m80 pasar á largos trancos por las avenidas, llevando como á remolque unos diminutos maridos sufocados, que no

\footnotetext{
9 A terminologia "texto ilustrado" foi cunhada em um trabalho que catalogou as publicações de $P B T$ entre 1904 e 1908. Ver em: (TARASIUK PLOC; WIZSNIACKI; 2019)
} 
pueden seguirlas". Após esse trecho, uma série de ironias exemplificam a inversão pontuada anteriormente, de modo que as mulheres modernas não seriam mais "hijas de Eva", mas sim "hijas del Tambor mayor" (posto de liderança de bandas marciais, tradicionalmente ocupado por homens altos), enquanto se perderiam as "memórias de Adão" para dar lugar às do "general Tom Pouce" (um ator com nanismo estadunidense que fez sucesso em peças circenses de meados do século XIX). O segundo momento do texto é introduzido pela citação das palavras de Marcel Prévost, um dramaturgo que entendia as mudanças corporais das mulheres como "efeito da prática de esportes e da vida cada vez mais ativa", enquanto "el hombre se encuentra cada vez más sujeito a una existencia sedentaria, en atmósfera deletéreas y en actitudes deprimientes".

O termo "virilidade" não aparece no texto, mas é evidente que a crítica do autor se dirige aos homens não-viris, tidos como inertes em comparação às mulheres: " $E l$ hombre seguiendo aí hará pronto el papel de enano de la reina, ser enfermizo, doliente $y$ atrofiado, con una marchita de viejecillo raquitico sobre un cuerpo de niño". O articulista termina por dizer que esse futuro reserva às mulheres a vitória, enquanto para os homens, a desgraça. O texto retoma, dessa forma, uma crítica ao feminismo associando-o a essa suposta "mudança prática" notada pelas "diferenças de estatura" e suas projeções. Uma interpretação possível é a de que a questão das estaturas seria apenas uma metáfora para os fenômenos realmente evidentes naquele contexto de tensão entre as relações de poder e de gênero. Contudo, traz o espectro da "desvirilização", ideia recorrente desde o final do século XIX, que apontava para a “degenerescência das energias másculas" e diminuição da força, de modo que a virilidade estaria em perigo (COURTINE, 2013b, p. 9). 


\section{Imagem 6 - O feminismo na Rússia}

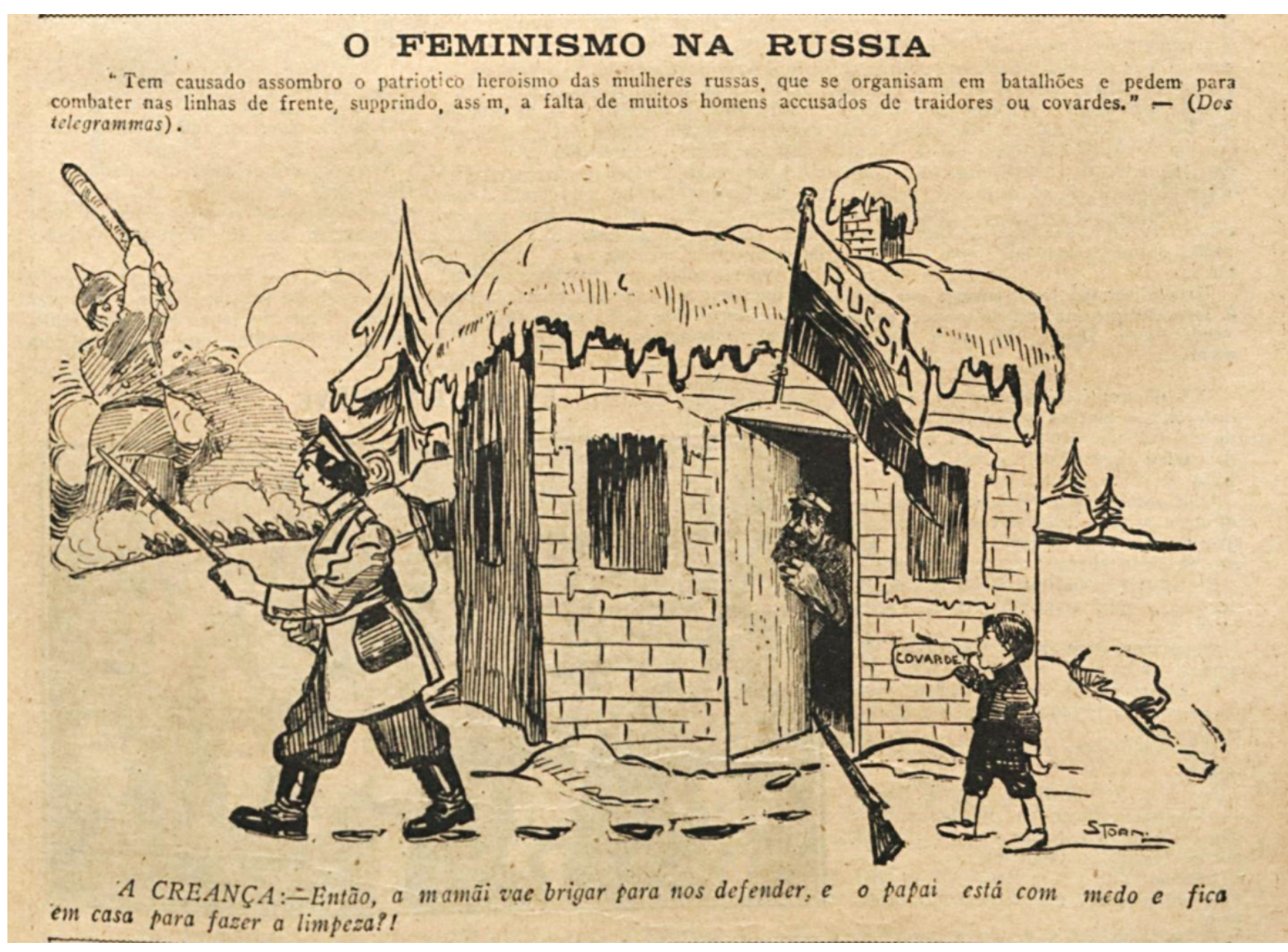

O feminismo na Rússia, charge de Storni, revista O Malho (Brasil), 4 de agosto de 1917. Reprodução do Acervo Digital da Fundação Biblioteca Nacional (BNDigital).

A ridicularização dos homens pouco viris aparece com certa frequência no contexto da Primeira Guerra Mundial (1914-1918). Isso porque a guerra e a virilidade têm laços fortes, pois "a guerra oferece a ocasião ao homem de prova a sua virilidade: a vaidade do uniforme, o orgulho da 'fina ferida', a coragem diante do risco de morte" (BARD, 2013b, p. 130). As notícias e rumores de homens amedrontados, que desertaram da guerra, apareceram em alguns noticiários da época e em revistas ilustradas. No mesmo dia, 4 de agosto de 1917, a Revista da Semana publicou na seção “Cartas de Mulher" um texto sobre a Legião Feminina da Morte, uma unidade militar russa composta apenas por mulheres e liderada por Maria Bochkareva - também 
lembrada como a “Joana D’Arc russa” (MAIA; CARDOSO; SANTOS, 2018, p. 72). Na charge de $O$ Malho, intitulada "O feminismo na Rússia", vemos a ilustração de uma mulher partindo para a guerra - armada e uniformizada - enquanto o seu marido a observa pela porta entreaberta, inerte no lar. A criança, que assiste à cena do lado de fora, repreende o próprio pai, atônito diante de sua covardia: "Então a mamãe vae brigar para nos defender, e o papai está com medo e fica em casa para fazer a limpeza?!". Nesse sentido, a humilhação da figura do homem é duplamente qualificada, pois seu comportamento é questionado por dois indivíduos de sua família que, segundo as concepções sexistas, deveriam ser submissos a ele: a sua esposa - que acaba cumprindo o seu papel na guerra - e o seu filho, uma criança - que o repreende verbalmente pela atitude.

De toda forma, não é apenas a conjuntura de guerra que baseia a publicação de $O$ Malho. A questão do sufrágio feminino estava em discussão no ano de 1917, especialmente na imprensa, pois em junho havia sido apresentada a primeira proposta de emenda da lei eleitoral que visava instituir o voto feminino no Brasil, promovida pelo deputado Maurício de Lacerda. Com isso, os debates sobre os "papéis" ou "esferas" de gênero ganhavam novo fôlego, operando na já conhecida imagem da inversão de posição entre homens e mulheres - uma metáfora da "desordem da sociedade". Assim sendo, esse discurso de gênero, que toma forma em charges como a destacada acima, mobilizava uma relação de alteridade: o homem fraco, covarde e traidor, carente de virilidade, recusa a guerra e é o alvo da chacota do articulista e ilustrador. Por sua vez, a mulher que incorpora o código viril, o ímpeto heroico e patriótico, aparece em cena para criar o contraste da inversão e "envergonhar" o seu par. Diferentemente de outras fontes que evocavam a imagem pejorativa da mulher que "foge ao ideal" como "masculinizada" (especialmente as mulheres feministas e sufragistas do início do século XX) (MOREIRA, 2021, p. 610), nos momentos decisivos da Grande Guerra as críticas foram mais direcionadas ao homem pouco viril. Nesse contexto, a mulher que manifestava virilidade aparecia em um sentido tolerável, e, muitas vezes, positivo. Fontes como essa demonstram bem o que a historiadora 
Christine Bard chama de "instrumentalização da virilidade" para as mulheres em tempos de guerra ${ }^{10}$.

\section{Imagem 7 - O feminismo guerreiro na Inglaterra}

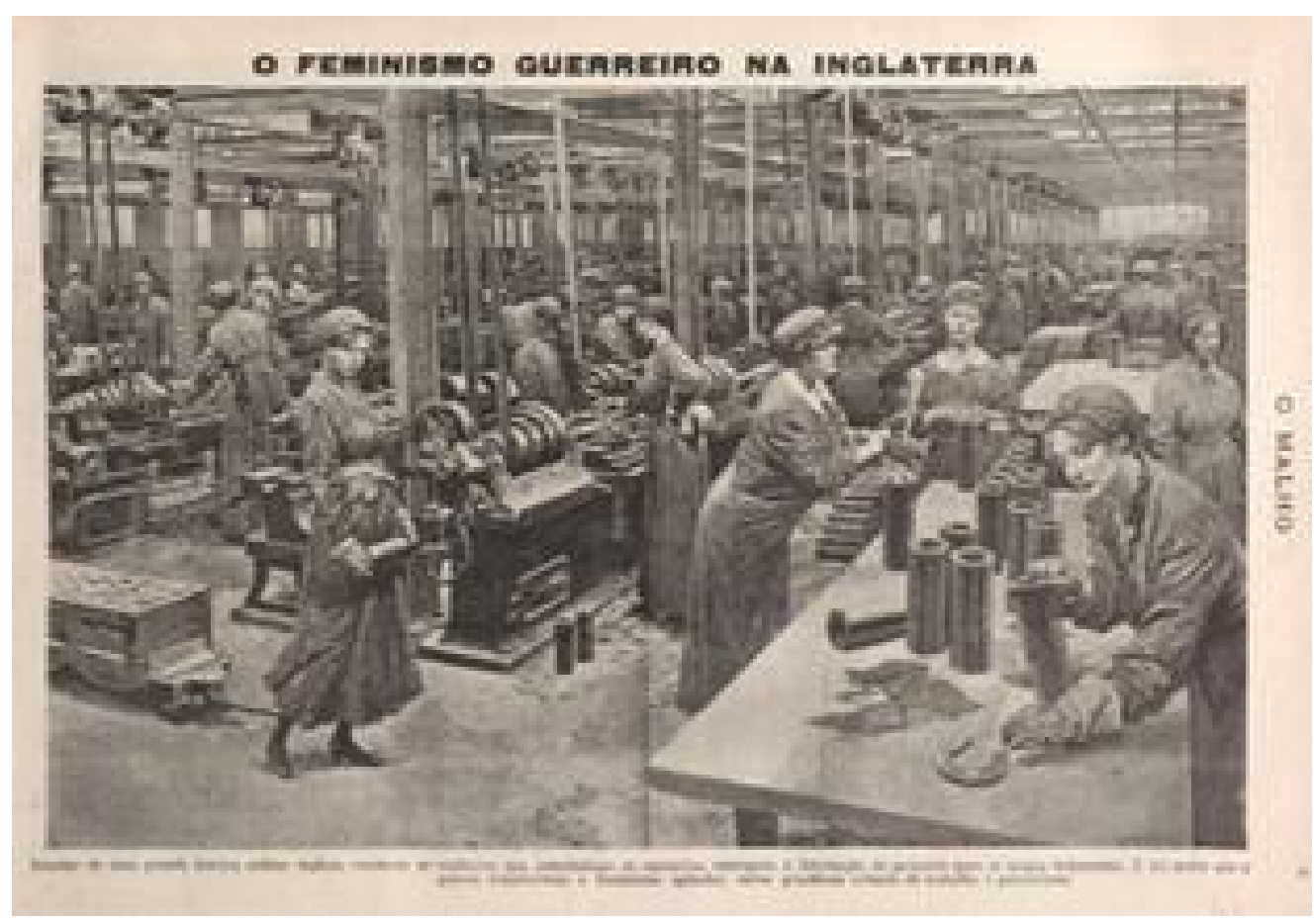

O feminismo guerreiro na Inglaterra, revista O Malho (Brasil), 9 de outubro de 1915. Reprodução do Acervo Digital da Fundação Biblioteca Nacional (BNDigital).

Com o decorrer da Primeira Guerra Mundial, as mulheres assumiram cada vez mais os postos de trabalho antes exclusivos aos homens, em especial nos setores importantes para o contexto de conflito, como a indústria bélica. A ilustração publicada em $O$ Malho mostra uma fábrica inglesa de munições, na qual vemos que a maioria das trabalhadoras é de mulheres. A legenda diz: "Interior de uma fabrica militar ingleza, vendo-se as mulheres, que substituiram os operarios, entregues à fabricação de projectis para as tropas britannicas. E foi assim que a guerra transformou o feminismo

\footnotetext{
${ }^{10}$ Vale ressaltar que em outros momentos históricos também ocorreu a "instrumentalização da virilidade" para as mulheres. Nos casos do Brasil e da Argentina, podemos citar o exemplo das guerras de independência, que, para além das suas particularidades, contaram com a participação de mulheres que se apropriaram dos códigos viris de sua época, como Maria Quitéria de Jesus (1792-1853) no Brasil e María Remedios del Valle (1768-1847) na Argentina.
} 
agitador, nessa grandiosa colmeia de trabalho e patriotismo". Nomeando essa ocupação das fábricas como um novo movimento - o "feminismo guerreiro" -, a revista $O$ Malho deixa clara a sua oposição à atuação feminista de até então - provavelmente por se tratar da Inglaterra, referindo-se mais especificamente às suffragettes da Women's Social and Political Union (WSPU). Além disso, não só manifesta a sua contrariedade ao que chama de "feminismo agitador", mas também insinua que o trabalho feminino na indústria bélica foi uma "solução" a ele. Importante destacar que a ilustração e a sua legenda não se utilizaram da abordagem humorística tal qual observamos anteriormente nas charges e textos ilustrados, o que pode nos indicar a intenção dos editores em enfatizar a sua "verossimilhança" sem dar margens a ambiguidades.

Na reportagem El feminismo y la guerra, publicada em 9 de janeiro de 1918 na revista $P B T$, também se manifesta a visão positiva da participação feminina em contexto de guerra. Segundo o texto publicado, a conjuntura do conflito colocava a mulher como "colaboradora" do homem, pois cumpria tarefas importantes e outras atividades da vida diária enquanto os homens estavam "ao lado dos canhões". O modo como o articulista aborda a temática enfatiza, de forma semelhante à $O$ Malho, que o "feminismo agitador" estava sendo superado em benefício de uma "cooperação" entre os sexos. Além disso, a reportagem termina com a provocação: "Queda ahora un interrogante abierto para cuando se haga la paz: ¿qué problemas sociales acarreará consigo este avance del feminismo, que ya es imposible contener?" (PBT, 1918). Nota-se que a menção ao "feminismo guerreiro" foi própria dos anos da Grande Guerra, especialmente na fala daqueles preocupados em enfatizar a excepcionalidade das mudanças na sociedade e da incorporação das mulheres em setores desfalcados. Para esses articulistas, as pautas feministas, como o sufrágio, não eram prioridade: a mulher deveria ser patriota, e não cidadã ${ }^{11}$.

\footnotetext{
${ }^{11}$ Apesar de não estar no escopo deste artigo, é relevante mencionar que certos discursos ideológicos sobre a "mulher patriótica", de forte teor conservador, ganharão muito espaço tanto na Europa como na América Latina a partir da década de 1920. Em 1919, o próprio Consejo Nacional de Mujeres da Argentina ingressou à chamada Liga Patriótica, organização nacionalista conservadora (LAVRIN, 2005, p. 326). No Brasil da década de 30, por sua vez, o Ação Integralista Brasileiro (AIB) investiu no discurso de "elevação e sublimação" do papel da mulher como mãe e educadora, que deveriam assumir os deveres com o lar e, principalmente, com a pátria (SIMÕES, 2011, p. 3).
} 
Compreender as representações como um campo de constante disputa e ressignificação nos permite observar que, apesar de tudo, algumas imagens que buscaram deslegitimar as suffragettes foram incorporadas de forma positiva pelas próprias militantes em algumas situações. A jornalista e feminista francesa, Jane Misme, escreveu em 1915 na revista La Française um texto que explicita a expectativa das feministas, pensando na experiência de guerra como um caminho para a igualdade profissional e política, "ajudando a romper uma barreira de séculos" (BARD e THÉBAUD, 1999, p. 152). O “feminismo guerreiro" também apareceu na revista francesa La Vie fémenine em 1917, cuja capa publicou uma ilustração elogiando o vigor das mulheres trabalhadoras, na qual duas figuras se destacam: a midinette, símbolo do trabalho feminino antes da guerra, e a grande e forte munitionnette, a "boa mulher viril" que trabalhava nas fábricas de munição (BARD e THÉBAUD, 1999, p. 152). Importante destacar, contudo, que essas representações positivas de mulheres viris no esforço de guerra são alcunhas que se aplicaram na prática às camadas pobres trabalhadoras, que serviram de mão de obra de substituição durante o período, cumprindo expectativas diferentes daquelas das mulheres das classes abastadas.

Portanto, "instrumentalizar a virilidade" para algumas mulheres não significou “torná-las homens". Além disso, o uso da imagem da "feminilidade viril" é diferente das representações presentes em repúdios da suposta "masculinização das mulheres", tão presente em discursos antifeministas. As "boas mulheres viris" foram produzidas atreladas a processos políticos, em contextos de guerra e reafirmação do nacionalismo. Em conjunturas diferentes, nas quais os propósitos políticos não atendiam ao patriotismo, a apropriação da virilidade pelas mulheres foi reprimida ou motivo para chacota. Apesar do início do século XX ter presenciado uma forte crença no estrito binarismo de gênero - nas supostas delimitações claras e fixas sobre o que seria da ordem do "feminino" ou "masculino", "viril" ou "débil" -, o que se percebe ao analisar as fontes da imprensa é justamente o contrário. Essas concepções se tensionam, se contradizem, se modificam de acordo com a conjuntura e são disputadas por diferentes grupos. Se em 1906, a revista feminina portenha Búcaro Americano, próxima de ideais 
liberais católicos, promovia a imagem da mulher emancipada como uma "redentora" e "regeneradora", que deveria buscar direitos civis sem "violar as leis eternas" ou "virilizar demasiado o sexo feminino", movendo "campanhas de paz para afastar a guerra" (ZANETTI, 1994, p. 269-270), durante o período da Grande Guerra é notável que, em parte da imprensa, essas ideias sobre o pacifismo e a atuação feminina serão avaliadas em outras medidas. Assim sendo, o olhar social sobre as mulheres viris era ambivalente: o desempenho viril era tolerado somente em alguns casos, como em determinadas práticas de exercícios físicos ou atuações patrióticas. Como destaca Bard (2013b, p. 142), "há lugar para a excentricidade...na medida em que ela não ofenda muito os bons costumes".

\section{Considerações finais}

A análise das publicações selecionadas de $P B T$ e $O$ Malho nos revela que as representações da virilidade na imprensa eram permeadas pelo viés de gênero, que organizava e legitimava determinadas normas e expectativas de papéis e comportamentos. As representações são múltiplas, pois não se restringem somente aos homens, são instrumentalizadas em contextos específicos e aparecem em diferentes abordagens, ora como um elogio, ora como uma rejeição de sua ausência. O crescimento dos feminismos foi um dos fatores que influenciaram essa série de textos e imagens opositoras, sendo o teor humorístico o meio para lhes satirizar, ridicularizar e deslegitimar. $\mathrm{O}$ antifeminismo, além disso, não se restringiu à crítica por si só: a sua retórica visa reafirmar e endossar convicções de caráter sexista, que seriam os "verdadeiros ideias legítimos para a ordem e a harmonia na sociedade". As fortes relações entre os posicionamentos antifeministas e as representações da virilidade se deram justamente pelas possibilidades de elogiar as normas de gênero hegemônicas e utilizar a "crise da virilidade" como argumento para criticar a atuação feminista muitas vezes atribuindo a ela a própria crise.

Os antifeminismos presentes nas duas revistas possuem traços semelhantes, mas as diferenças são observáveis tanto nas abordagens, como nas conjunturas políticas 
específicas de cada país. São acontecimentos pontuais e notícias - fossem locais ou internacionais - que motivam a produção desses textos e imagens. Assim sendo, o olhar cuidadoso perante o conceito da virilidade permite uma análise histórica mais apurada, rejeitando lugares-comuns e simplificações que tendem a naturalizar e imortalizar determinados códigos e comportamentos humanos.

$\mathrm{O}$ discurso da revista argentina $P B T$ foi predominantemente inquieto e atrelado à ideia de feminismo como "ameaça à sociedade". As fontes apresentam textos mais extensos, seja na história em quadrinhos (viñetas humorísticas), seja nos textos ilustrados, o que indica um posicionamento antifeminista caracterizado pela disputa argumentativa, permeada por ironias, lamentações e insultos. Observa-se que o olhar de seus articulistas é mais centrado na imaginação dos "possíveis efeitos do feminismo na sociedade". O conteúdo de suas publicações muitas vezes dialoga com referenciais europeus, inclusive no que tange às "partidárias feministas" mencionadas - por vezes implicitamente a ideia de militante feminista é atrelada à das suffragettes inglesas, o que servia como modo de homogeneizar e estigmatizar as feministas, pois salientava uma radicalidade repudiada pela imprensa da época. Os textos são repletos de projeções de gênero que rejeitam as aparências e os comportamentos "divergentes", tanto de homens como de mulheres, revelando a ansiedade desses autores em interpretar, do ponto de vista dominante, o impacto das reivindicações feministas cada vez mais em evidência na Argentina e no exterior.

As fontes do periódico carioca $O$ Malho, por sua vez, priorizam chacotas e deturpações do termo "feminismo". São predominantemente iconográficas, de forma que parte significativa da mensagem e do sentido é expressa nas charges e demais ilustrações, por meio de personagens, movimentos e cenas específicas. As publicações remetem aos feminismos como fenômenos locais e pontuais, com cenas no Rio de Janeiro, Rússia e Inglaterra. A representação da virilidade é sempre associada a uma ressignificação do sentido de "feminismo", de modo que o sentido político dos ideais feministas era banalizado, perdido ou distorcido. Os articulistas e caricaturistas brasileiros, com mais frequência que os argentinos, evidenciaram em suas produções a 
ideia de que existe um "bom feminismo" em contraste ao feminismo militante, visto como "agitador" e "desnecessário". São posicionamentos marcados por juízos de valor e atitudes arbitrárias que delimitavam quem eram "as boas feministas" ou não. O "feminismo bem-comportado" aparece aqui não como um modelo moderado de atuação feminista, mas sim como discurso produzido e reivindicado pelos antifeministas de $O$ Malho. Seja esse "feminismo" chamado de carioca, russo ou inglês, o determinante era que seu significado cultuasse a pátria, a ordem e a sujeição das mulheres.

\section{Referências bibliográficas}

\section{Arquivos (Acervos digitais)}

O Malho: Hemeroteca Digital Brasileira - Fundação Biblioteca Nacional. Disponível em: <https://bndigital.bn.gov.br/hemeroteca-digital/>. Acesso em: 12 dez. 2021.

PBT: Ibero-Amerikanisches Institut - Preußischer Kulturbesitz. Disponível em: $<$ https://digital.iai.spk-berlin.de/viewer/index/>. Acesso em: 12 dez. 2021.

\section{Bibliografia}

ALBUQUERQUE JÚNIOR, Durval Muniz de. Nordestino: invenção do "falo" - uma história do gênero masculino (1920/1940). 2a Edição. São Paulo: Intermeios, 2013.

ALVES, Branca Moreira. A luta das sufragistas. In: HOLLANDA, Heloisa Buarque de. (org.) Pensamento feminista brasileiro, formação e contexto. Rio de Janeiro: Bazar do Tempo, 2019.

BARD, Christine (org.). Un siècle d'antiféminisme. Paris: Éditions Fayard, 1999.

BEN, Pablo. Cuerpos femeninos y cuerpos abyectos. La construción anatómica de la feminidad em la medecina argentina. In: GIL LOZANO, Fernanda; PITA, Valeria; INI, Gabriela (dir.). Historia de las mujeres en la Argentina, Colonia y siglo XIX, Tomo I. Buenos Aires: Taurus, 2000.

BERGSON, Henri. O riso: ensaio sobre a significância do cômico. Rio de Janeiro: Zahar Editores, 1983. 
BERNARDES, Maria Thereza Caiuby Crescenti. Mulheres de ontem? Rio de Janeiro, século XIX. Brasil, T.A. Queiroz, 1989.

BESSE, Susan K. Modernizando a desigualdade: reestruturação da ideologia de gênero no Brasil, 1914-1940. São Paulo: Edusp, 1999.

BLACKWELDER, Julia Kirk; JOHNSON, Lyman L. Changing Criminal Patterns in Buenos Aires, 1890 to 1914. Journal of Latin American Studies, 14, p. 359-379, 1982, doi:10.1017/S0022216X00022458.

BURKART, M. De Caras y Caretas a Hum ${ }^{\circledR}$ : a imprensa de humor gráfico na Argentina do século XX. Revista USP, n. 88, p. 26-37, 1 fev. 2011.

CHARTIER, Roger. A história cultural: entre práticas e representações. $2^{\mathrm{a}}$ edição." Col. Memória e Sociedade. Difel: Algés, 2002.

CHARTIER, Roger. Diferenças entre os sexos e dominação simbólica (nota crítica). Cadernos Pagu, v. 4, p. 37-47, 1995.

CORBIN, Alain; COURTINE, Jean-Jacques; VIGARELLO, Georges. História da Virilidade. Vol. 2 (O triunfo da virilidade. O século XIX). Petrópolis: Vozes, 2013a.

CORBIN, Alain; COURTINE, Jean-Jacques; VIGARELLO, Georges. História da Virilidade. Vol. 3 (A virilidade em crise? Séculos XX-XXI). Petrópolis: Vozes, $2013 \mathrm{~b}$.

FLORES, Ana Beatriz, et al. Diccionario crítico de términos del humor y breve enciclopedia de la cultura humorística argentina. Córdoba: Universidad Nacional de Córdoba, 2014.

FRANCO, Stella Maris Scatena. "Gênero em debate: problemas metodológicos e perspectivas historiográficas”. In: VILLAÇA, Mariana; PRADO, Maria Ligia C. (org.). História das Américas: fontes e abordagens historiográficas. SP: Humanitas/Capes, 2015. (p. 36 a 51).

GAY, Peter. A experiência burguesa: da Rainha Vitória a Freud. 1. A educação dos sentidos. São Paulo: Companhia das Letras, 1988 [1984].

GONÇALES, Guilherme Domingues. Mulheres engravatadas: moda e comportamento feminino no Brasil, 1851-1911. Dissertação (mestrado) - Faculdade de Filosofia, Letras e Ciências Humanas, Universidade de São Paulo, 2019.

HOOKS, Bell. Ensinando a transgredir: a educação como prática da liberdade. São Paulo: Martins Fontes, 2013. 
LAQUEUR, Thomas. Inventando o sexo. Corpo e gênero dos gregos a Freud. Rio de Janeiro: Relume Dumará, 2001.

LAVRIN, Asunción. Mujeres, feminismo y cambio social en Argentina, Chile y Uruguay 1890-1940. Santiago, Chile: Ediciones de la Dirección de Bibliotecas, Archivos y Museos, 2005.

LÓPEZ, Elvira. El movimiento feminista: primeros trazos del feminismo em Argentina (1901), Buenos Aires: Biblioteca Nacional, 2009. Disponível em: < https://www.bn.gov.ar/micrositios/admin_assets/issues/files/72971dd6d3d84b12f47a090 d80d523e4.pdf $>$ Acesso em julho de $202 \overline{1}$.

MAIA, Andrea Casa Nova (Org.), CARDOSO, Luciene Carris e SANTOS, Vicente S. M. dos. Russos em revista: a Revolução Russa nas revistas ilustradas brasileiras. Rio de Janeiro: Gramma, 2018.

MARQUES NETO, C. F. Da necessidade de uma "nova" escola só para moças: Henrique Castriciano de Souza e a modernidade pedagógica norte-riograndense (1911-1923). 2016. 176 f. Dissertação (Mestrado em História) - Programa de Pós-Graduação em História, Centro de Humanidades, Universidade Federal de Campina Grande, Paraíba, Brasil, 2016.

MOREIRA, Thaís Batista Rosa. "O antifeminismo e o antissufragismo em publicações das revistas ilustradas humorísticas "O Malho" e "Careta" (1917-1932)". In: ENCONTRO DE PESQUISA NA GRADUAÇÃO EM HISTÓRIA (EPEGH), 6., 2018, São Paulo. Anais eletrônicos: VI Encontro de Pesquisa na Graduação em História [...]. São Paulo: FFLCH/USP, 2021. 762 p. ISBN 978-65-87621-39-5. Disponível em: $<$ https://sites.usp.br/pet/vi-epegh-publicacao-dos-anais/>. Acesso em: 7 maio 2021.

OLIVEIRA, Cláudia de. A iconografia do moderno: a representação da vida urbana. In: LINS, Vera; OLIVEIRA, Cláudia de; VELlOSO, Monica Pimenta. O Moderno em revistas - Representações do Rio de Janeiro de 1890 a 1930. Rio de Janeiro: Garamond, 2010.

PATTERSON,Martha H. Beyond the Gibson Girl: Reimagining the American New Woman, 1895-1915. Urbana e Chicago: University of Illinois Press, 2010.

PRADO, Natalia Martínez. La emergência del feminismo en la Argentina: un análisis de las tramas discursivas a comienzos del siglo XX. Estudos Feministas, Florianópolis, 23(1), p. 71-97, janeiro-abril/2015.

ROCHEFORT, Florence. L'antiféminisme à la Belle Époque, une rhétorique réactionnaire. In: BARD, Christine (org.). Un siècle d'antiféminisme. Paris : Éditions Fayard, 1999. 
SALIBA, Elias T. História cultural do humor: balanço provisório e perspectivas de pesquisas. Revista de História, São Paulo, n. 176, p. 1-39, 2017.

SCHPUN, Mônica Raisa. Beleza em jogo: Cultura física e comportamento em São Paulo nos anos 20. São Paulo: Boitempo, 1999.

SCOTT, Joan W. Gênero: uma categoria útil de análise histórica. Educação e Realidade, Porto Alegre, v.20, n.2, 1995, p. 71-99.

SIMÕES, Renata Duarte. Nem só mãe, esposa e professora: os múltiplos campos de atuação da mulher militante integralista. In: XXVI Simpósio Nacional de História, 2011, São Paulo. Anais do XXVI Simpósio Nacional de História. São Paulo, 2011. v. único. Disponível em:

em: $\quad<$

https://anpuh.org.br/uploads/anais-simposios/pdf/2019-01/1548856706_a5564fa740293

28fae172db261cad8a9.pdf> Acesso em julho de 2021.

SOIHET, Rachel. Feminismos e antifeminismos: Mulheres e suas lutas pela conquista da cidadania plena. Rio de Janeiro: 7 Letras, 2013.

TARASIUK PLOC, Laura Ivana; WIZSNIACKI, Mariano: La ilustración en los inicios de la Revista PBT (1904-1908). Prensa, comunicación visual y sátira política. $X$ Jornadas de Jóvenes Investigadorxs. Instituto de Investigaciones Gino Germani. 2019, p.11-12. Disponível em: < http://jornadasjovenesiigg.sociales.uba.ar/wp-content/uploads/sites/107/2020/09/eje4_ta rasiuk_wiszniacki-PON.doc.docx> Acesso em maio de 2021.

VELLOSO, Mônica P. Sensibilidades modernas: as revistas literárias e de humor no Rio da Primeira República. In: LUSTOSA, Isabel (org.) Imprensa, História e Literatura. Rio de Janeiro: Edições Casa de Rui Barbosa, 2008.

ZANETTI, Susana E. Búcaro Americano: Clorinda Matto de Turner en la escena feminina porteña. In: FLETCHER, Lea (Comp.) Mujeres y Cultura en la Argentina del siglo XIX. Buenos Aires: Feminaria, 1994. 